\title{
Histamine-release test in angioedema patients without urticaria - a retrospective cohort study of 404 patients
}

\author{
${ }^{1}$ Department of Dermatology and Allergy Centre, Odense University Hospital, Odense, Denmark \\ ${ }^{2}$ Department of Otorhinolaryngology, Head and Neck Surgery and Audiology, Rigshospitalet, University of Copenhagen, \\ København, Denmark
}

\section{KEY WORDS}

monosymptomatic angioedema;

histamine-release test; urticaria;

antihistamines; corticosteroids; adrenaline

\section{Corresponding author}

Georg Authried

Department of Dermatology

and Allergy Centre

Odense University Hospital

Kløvervænget 15, 5000 Odense C, Denmark

Phone: +4565412705

E-mail: georg.authried@rsyd.dk

\section{DOI}

10.23822/EurAnnACI.1764-1489.58

\begin{abstract}
Summary
A subset of patients with angioedema (AE) and urticaria has histamine releasing autoantibodies. The histamine release test (HR-test) has been used as a tool in chronic urticaria to define the autoimmune subgroup and may possibly guide the clinician to a more personalized therapy, like omalizumab and cyclosporine. The prevalence and value of positive histamine releasing autoantibodies in monosymptomatic $A E$ is sparsely described in the literature. The purpose of this study was to report the prevalence of positive histamine releasing autoantibodies in a cohort of patients with recurrent $A E$ and evaluate the usefulness of this test in $A E$ patients. We performed a retrospective cohort study of 612 patients referred due to AE between 1995 and 2013. HR-test results were available in 404 patients. In the sub-group of patients with $A E$ and urticaria, $17.3 \%$ had a positive HR-test but only $4.3 \%$ of patients with mono-symptomatic $A E$ had a positive HR-test. No statistically significant treatment benefits of antihistamines, corticosteroids or adrenaline were found comparing patients with angioedema +- urticaria based on the result of the HR-test (negative / positive). Thus, the HR-test result cannot be used as predictor of the efficacy of anti-allergic treatment.
\end{abstract}

\section{Introduction}

Angioedema (AE) is a non-pitting skin colored swelling of skin or mucosa, with a predilection for areas with loosely bound skin. It is caused by a temporary increase in vascular permeability due to vasoactive mediators.

Mostly, AE is accompanied by urticaria, which indicates activation of mast cells liberating histamine and other vasoactive mediators. A subset of patients with urticaria and AE has histamine-releasing autoantibodies. The basophil histamine release test (HR-test) is a remedy to identify activation of basophils or mast cells causing histamine release. It has been used as a tool in chronic urticaria (CU) to define the autoimmune subgroup, and it is the current gold standard to detect histamine releasing autoantibodies to the FceRI and less frequently against $\operatorname{IgE}(1,2)$.
Functional histamine releasing autoantibodies have been identified by the HR-test in approximately $20-30 \%$ of patients with CU (2-6). In contrast to CU or AE accompanied with urticaria, where histamine releasing autoantibodies can be frequently detected, sparse data can be found on the prevalence of histamine releasing autoantibodies in recurrent idiopathic $\mathrm{AE}(7)$.

The objective of this study was to report the prevalence of positive histamine releasing autoantibodies in a cohort of patients with recurrent idiopathic $\mathrm{AE}$, and evaluate the usefulness of HR-test in this patient group.

\section{Patients and methods}

This was a retrospective cohort study of 612 AE patients seen at the Department of Dermatology, Odense University Hos- 
pital, in the study period 1995-2013. All patients had been referred for specialized dermatologic evaluation, due to $\mathrm{AE}$ with or without urticaria. The study-population was identified by a search in the medical record system, using the International Classification of Disease version 10 (ICD-10) diagnostic codes T78.3 (angioneurotic edema / Quinke oedema / giant urticaria), L50.8 (urticaria, other), L50.8A (chronic urticaria) and L98.9 (disorder of the skin and subcutaneous tissue, unspecified). Patients were included in the cohort if the information in the medical records were in accordance with AE, with or without urticaria. Patients with complement $\mathrm{C} 1$ inhibitor deficiency and acquired complement $\mathrm{C} 1$ inhibitor deficiency, as well as patients with a history of angiotensin-converting enzyme inhibitor-induced angioedema, were excluded. Only AE patients who had a HR-test performed were included in this study (404 patients). Figure 1 demonstrates the process of inclusion and exclusion of patients. A consultant dermatologist or a resident reviewed the medical records. Relevant data on demographics, concomitant rash, co-morbidity, co-medication, treatment regimens and efficacy, hospital admissions and outcome were collected, as well as selected laboratory test results.

HR-test was analyzed at RefLab Aps Copenhagen (http://reflab. $\mathrm{dk} /$ ). According to this laboratory, the threshold for a positive result was $>16.5 \%$ histamine release.

\section{Ethical considerations}

This study was approved by the Danish Data Protection Agency (Journal number 2008-38-0035) and the Danish National Board of Health (Journal number S-20140165).

\section{Statistical analysis}

Patients with AE with or without urticaria were compared using Fisher's exact test. Difference of proportion test and odds ratio calculations was employed when comparing treatment efficacy. P-values $\leq 0.05$ were considered statistically significant. $95 \%$ confidence intervals (CI) were reported when appropriate.

\section{Results}

The study population comprised 612 patients. HR-test was performed in 404 patients meeting the study's inclusion criteria. The male : female ratio was 0.73 , with a mean age of 50.2 years (range 2-85 years). The cohort was almost exclusively Caucasian. The mean follow-up time was 66.4 weeks. Further details are shown in table I. In two patients the test results could not be retrieved, and in three patients it was uncertain from the medical record if they also had urticaria. These five patients were excluded (figure 1). The HR-test was positive in 10 out of 231 patients with AE without urticaria (4.3\%) and in 29 out of 168 patients with

Figure 1 - Flow-chart demonstrating the process of selecting patients with positive HR-test.

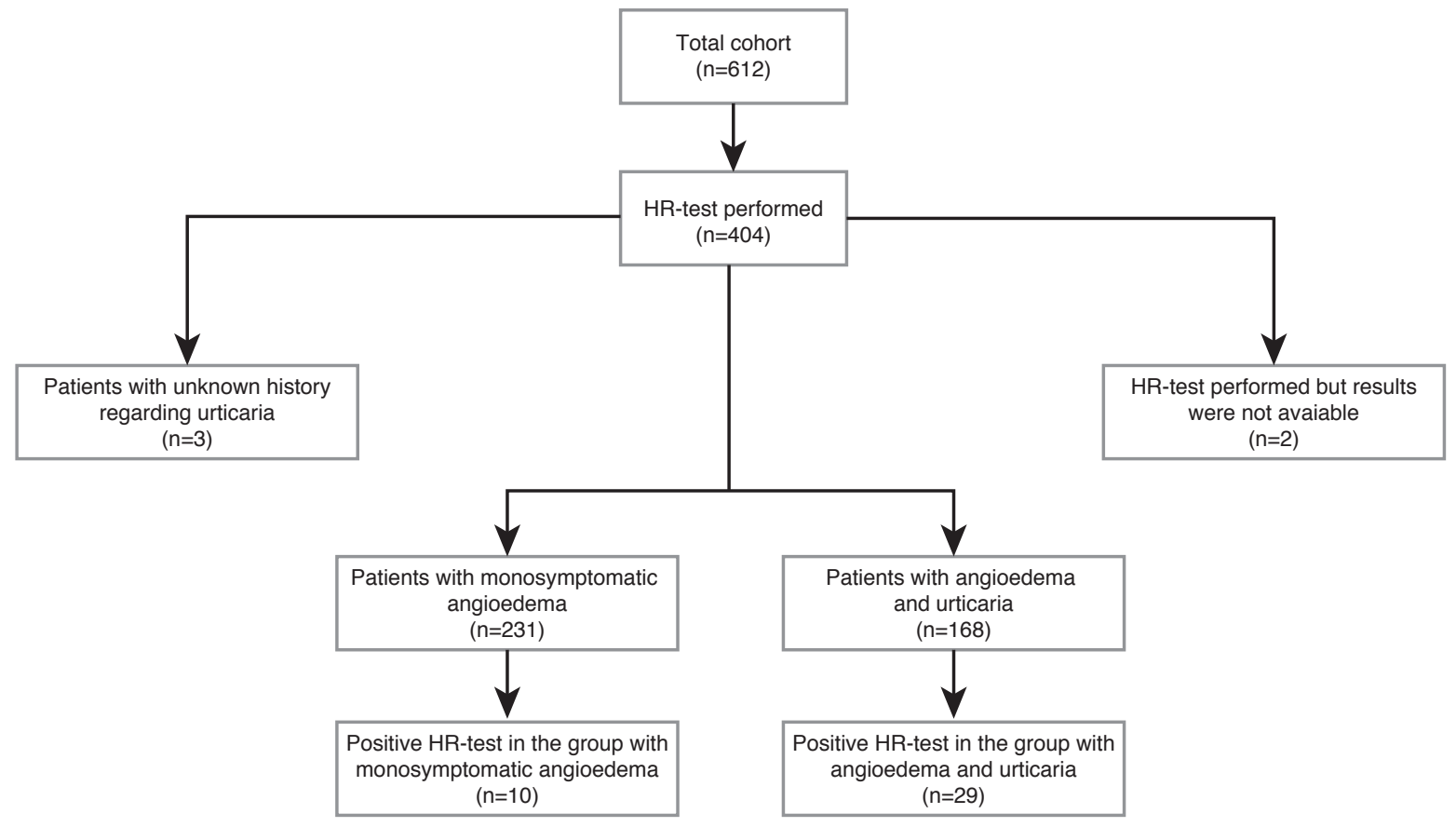


Table I - Demographic and clinical data of patients with angioedema $(A E)+$ - urticaria.

\begin{tabular}{|c|c|}
\hline $\begin{array}{l}\text { Total number of patients } \\
\text { with HR-test performed }\end{array}$ & 404 \\
\hline males & 171 \\
\hline females & 233 \\
\hline$m:$ f-ratio & 0.73 \\
\hline Age, mean, median, [range], years & $\begin{array}{l}\text { 50.16, 51.39, } \text { [range } \\
2.1-85.1 \text { years] }\end{array}$ \\
\hline \multicolumn{2}{|l|}{ Ethnicity } \\
\hline Caucasian & 393 \\
\hline Middle Eastern & 3 \\
\hline Black & 1 \\
\hline Asian & 5 \\
\hline other & 1 \\
\hline \multicolumn{2}{|l|}{ Current tobacco use, $\mathrm{n}$} \\
\hline yes & 70 \\
\hline no & 188 \\
\hline unknown & 146 \\
\hline $\begin{array}{l}\text { Number of patients with a positive } \\
\text { family history of AE }\end{array}$ & 31 \\
\hline Number of HR-tests, total & 404 \\
\hline positive & $39(9.7 \%)$ \\
\hline negative & $360(89.1 \%)$ \\
\hline unknown result & $5(0.5 \%)$ \\
\hline \multicolumn{2}{|l|}{ Comorbidities } \\
\hline diabetes mellitus & 32 \\
\hline hypertension & 115 \\
\hline ischemic heart disease & 24 \\
\hline heart failure & 7 \\
\hline atopic dermatitis & 21 \\
\hline allergic rhinitis & 56 \\
\hline asthma & 42 \\
\hline other respiratory disease & 4 \\
\hline $\begin{array}{l}\text { Follow-up time, mean ; [range], } \\
\text { weeks }\end{array}$ & 66.4; [0 - 675 weeks $]$ \\
\hline $\begin{array}{l}\text { Number of reported efficacy of } \\
\text { antihistamines }\end{array}$ & 266 \\
\hline $\begin{array}{l}\text { Number of reported efficacy of } \\
\text { corticosteroids }\end{array}$ & 162 \\
\hline $\begin{array}{l}\text { Number of patients hospitalized } \\
\text { due to } \mathrm{AE}\end{array}$ & $138(34.2 \%)$ \\
\hline $\begin{array}{l}\text { Number of patients with ER visits } \\
\text { due to } \mathrm{AE}\end{array}$ & $144(35.6 \%)$ \\
\hline
\end{tabular}

Table II - Different treatments and their efficacy on angioedema patients + - urticaria.

\begin{tabular}{|c|c|c|c|}
\hline & Medications & $\begin{array}{c}\text { Number } \\
\text { of treated } \\
\text { individuals }\end{array}$ & $\begin{array}{c}\text { Efficacy on } \\
\text { angioedema }\end{array}$ \\
\hline \multirow{3}{*}{$\begin{array}{l}\text { positive } \\
\text { HR-test and } \\
\text { monosymptomatic } \\
\text { angioedema } \\
(\mathrm{n}=10)\end{array}$} & anti-histamines & 10 & $5(50 \%)$ \\
\hline & corticosteroids & 7 & $4(92.9 \%)$ \\
\hline & adrenaline & 3 & $2(66.7 \%)$ \\
\hline \multirow{3}{*}{$\begin{array}{l}\text { negative } \\
\text { HR-test and } \\
\text { monosymptomatic } \\
\text { angioedema } \\
(\mathrm{n}=221)\end{array}$} & anti-histamines & 202 & $132(65.3 \%)$ \\
\hline & corticosteroids & 134 & $80(59.7 \%)$ \\
\hline & adrenaline & 34 & $14(41.2 \%)$ \\
\hline \multirow{3}{*}{$\begin{array}{l}\text { positive HR-test } \\
\text { and angioedema } \\
\text { with urticaria } \\
(\mathrm{n}=29)\end{array}$} & anti-histamines & 27 & $22(81.5 \%)$ \\
\hline & corticosteroids & 20 & $13(65 \%)$ \\
\hline & adrenaline & 3 & $1(33.1 \%)$ \\
\hline \multirow{3}{*}{$\begin{array}{l}\text { negative HR-test } \\
\text { and angioedema } \\
\text { with urticaria } \\
(\mathrm{n}=139)\end{array}$} & anti-histamines & 135 & $107(79.3 \%)$ \\
\hline & corticosteroids & 86 & $65(75.6 \%)$ \\
\hline & adrenaline & 14 & $5(35.7 \%)$ \\
\hline
\end{tabular}

$\mathrm{AE}$ and urticaria (17.3\%) ( $\mathrm{p}=0.0005,95 \%$ CI 5.64 to 20.14$)$. Among 399 included patients, sufficient treatment data were available in 374 patients. Table II shows the different drugs used and their efficacy. When monosymptomatic AE patients with positive HR-test were compared with monosymptomatic AE having a negative HR-test, the odds ratio was 1.9 for a positive effect of antihistamines. This finding was not significant (p $=0.25,95 \%$ CI 0.528 to 6.7352 ). Comparing the same groups, the odds ratio was 1.1 ( $\mathrm{p}=0.59,95 \%$ CI 0.2391 to 5.1635$)$ for having a positive effect of corticosteroids.

The treatment efficacy of antihistamines and corticosteroids was also studied among AE patients with concomitant urticaria. The subgroup of patients with positive HR-test was compared with patients having negative HR-test. The odds ratio was 0.86 (p $=0.51,95 \%$ CI $0.302-2.498)$ for having a positive effect of antihistamines, and 1.67 ( $\mathrm{p}=0.24,95 \%$ CI $0.5878-4.7261)$ for corticosteroids. The treatment response of adrenaline could also not be predicted by HR-test result, as those with monosymptomatic angioedema and positive versus negative HR-test had an odds ratio of 0.71 ( $\mathrm{p}=0.64,95 \%$ CI $0.0589-8.6651)$. Patients with concomitant urticaria and positive versus negative HR-test had an odds ratio of 1.11 ( $\mathrm{p}=0.73,95 \%$ CI 0.0795 $-15.5348)$. 
Table III - HR-test results from studies of patients with urticaria (wheals) and angioedema (AE) also showing cut-off values for HR-test.

\begin{tabular}{|c|c|c|c|c|c|c|}
\hline Author & $\begin{array}{l}\text { Basophil hista- } \\
\text { mine release test } \\
(\mathrm{HR})\end{array}$ & $\begin{array}{c}\text { Number of } \\
\text { patients with } \\
\text { monosymp- } \\
\text { tomatic AE }\end{array}$ & $\begin{array}{c}\text { Number of } \\
\text { patients with } \\
\text { AE with wheals }\end{array}$ & $\begin{array}{l}\text { Number of pa- } \\
\text { tients with only } \\
\text { wheals }\end{array}$ & $\begin{array}{l}\text { Number } \\
\text { of healthy } \\
\text { controls }\end{array}$ & $\begin{array}{c}\text { Total positive } \\
\text { HR }\end{array}$ \\
\hline $\begin{array}{l}\text { Iqbal et al. } \\
2012(3)\end{array}$ & $>16.5 \%$ cut-off & & & $\begin{array}{c}398 \text { (urticaria with } \\
\text { and without } A E \text { ) } \\
105 \text { positive } \mathrm{HR}\end{array}$ & & 105 \\
\hline $\begin{array}{l}\text { Grattan et al. } \\
1991(4)\end{array}$ & $>10 \%$ cut-off & & & $\begin{array}{c}25, \\
14 \text { positive HR }\end{array}$ & $\begin{array}{c}10 \\
0 \text { positive HR }\end{array}$ & 14 \\
\hline $\begin{array}{l}\text { Hide et al. } \\
1993(5)\end{array}$ & $>10 \%$ cut-off & & & $\begin{array}{c}26, \\
17 \text { positive HR }\end{array}$ & & 17 \\
\hline $\begin{array}{l}\text { Tedeschi et al. } \\
2012(7)\end{array}$ & $5 \%$ cut-off & $\begin{array}{c}19 \\
2 \text { positive HR }\end{array}$ & $\begin{array}{c}38,18 \\
\text { positive HR }\end{array}$ & $\begin{array}{c}52, \\
11 \text { positive HR }\end{array}$ & $\begin{array}{c}20, \\
0 \text { positive HR }\end{array}$ & $\begin{array}{c}31 \text { (2 AE, } 18 \\
\text { AE with wheals, } \\
11 \text { with wheals) }\end{array}$ \\
\hline $\begin{array}{l}\text { Grattan et al. } \\
2000(10)\end{array}$ & $>5 \%$ cut-off & & & $\begin{array}{c}27 \\
14 \text { positive HR }\end{array}$ & & 14 \\
\hline $\begin{array}{l}\text { Platzer et al. } \\
2005 \text { (11) }\end{array}$ & $>16.5 \%$ cut-off & & & $\begin{array}{c}901, \\
323 \text { positive HR }\end{array}$ & $\begin{array}{c}9 \\
0 \text { positive HR }\end{array}$ & 323 \\
\hline $\begin{array}{l}\text { Szegedi et al. } \\
2006 \text { (12) }\end{array}$ & $\begin{array}{l}11.6 \% \text { cut-off } \\
\text { for atopic donor } \\
\text { serum } \\
\text { 7,3\% cut-off for } \\
\text { non-atopic serum }\end{array}$ & & & $\begin{array}{c}72, \\
37 \text { positive atopic } \\
\text { donor serum, } 23 \\
\text { positive non- atop- } \\
\text { ic donor serum }{ }^{1}\end{array}$ & $\begin{array}{c}20, \\
0 \text { positive HR }\end{array}$ & 60 \\
\hline $\begin{array}{l}\text { Zuberbier et } \\
\text { al. } 2000 \text { (13) }\end{array}$ & $>10 \%$ cut-off & & & $\begin{array}{c}13 \\
7 \text { positive HR }\end{array}$ & & 7 \\
\hline $\begin{array}{l}\text { Godse et al. } \\
2010 \text { (14) }\end{array}$ & $>16.5 \%$ cut-off & & & $\begin{array}{c}20, \\
9 \text { positive HR }\end{array}$ & & 9 \\
\hline $\begin{array}{l}\text { Hyry et al. } \\
2006 \text { (15) }\end{array}$ & $>12 \%$ cut-off & & & $\begin{array}{c}10 \\
4 \text { positive HR }\end{array}$ & & 4 \\
\hline $\begin{array}{l}\text { Sabroe et al. } \\
1999(16)\end{array}$ & $\geq 5 \%$ cut-off & & & $\begin{array}{c}155 \\
54 \text { positive HR }\end{array}$ & $\begin{array}{c}40 \\
0 \text { positive HR }\end{array}$ & 54 \\
\hline $\begin{array}{l}\text { Kaplan, } \\
\text { Joseph. } 2007 \\
(17)\end{array}$ & $\geq 15 \%$ cut-off & & & $\begin{array}{c}104 \\
54 \text { positive HR }\end{array}$ & & 54 \\
\hline $\begin{array}{l}\text { Perez et al. } \\
2010 \text { (18) }\end{array}$ & $>16.5 \%$ cut-off & & & $\begin{array}{l}6 \text { (where HR test } \\
\text { was performed), } 2 \\
\text { positive HR with } \\
\text { CU, } 1 \text { positive with } \\
\text { urticarial vasculitis }\end{array}$ & & 3 \\
\hline $\begin{array}{l}\text { Berti et al. } \\
2017 \text { (19) }\end{array}$ & $>16.5 \%$ cut-off & & 14 & 6 & & $\begin{array}{l}9 \text { out of the } 20 \\
\text { patients had a } \\
\text { positive HR test }\end{array}$ \\
\hline This study & $>16.5 \%$ cut-off & $\begin{array}{c}231, \\
10 \text { positive HR }\end{array}$ & $\begin{array}{c}168 \\
29 \text { positive HR }\end{array}$ & & & 39 \\
\hline
\end{tabular}

${ }^{1}$ Atopic serum leads to a significantly higher histamine release. HR-test performed with blood from two donors. 


\section{Discussion}

In this retrospective study of 404 patients, we analyzed the frequency of functional histamine releasing autoantibodies in a cohort of patients with $\mathrm{AE}$ with or without urticaria. We found a frequency of $4.3 \%$ with a positive HR-test in the subgroup of patients with mono-symptomatic $\mathrm{AE}$, and $17.3 \%$ with a positive HR-test in the subgroup of patients with $\mathrm{AE}$ and urticaria. This makes sense, since the wheal and flare response is most often connected to histamine release, whereas the vasoactive mediators in angioedema are more dubious and may include other mediators such as bradykinin (8).

Comparing patients with mono-symptomatic $\mathrm{AE}$ with positive HR-test contra negative HR-test, the odds ratio was 1.9 for having a positive effect of antihistamines. This could be a signal to guide in an individualized therapy, but unfortunately the finding was not significant, possibly due to the number of included patients. In a large clinical survey, it has been shown that most patients (254 of 294) with monosymptomatic AE responded completely or partially to antihistamines, however no data on the HR-test was provided (9).

In the subgroup of $\mathrm{AE}$ patients with co-existing urticaria, neither the treatment efficacy of antihistamines, corticosteroids nor adrenaline differed significantly between HR-positive and HR-negative individuals. Unfortunately, we could not retrieve sufficient efficacy data of cyclosporine in this study. It is known from the literature that patients with antihistamine-unresponsive urticaria and a positive HR-test may respond better to cyclosporine than patients with a negative HR-test $(3,10)$. No data on monosymptomatic angioedema, HR-test and treatment response to cyclosporine or other drugs could be found.

Sparse data could be found in the literature on HR-testing in patients with angioedema (7). Only the study by Tedeschi and coworkers investigated HR-testing in monosymptomatic angioedema patients. They divided their cohort into subgroups of patients with $\mathrm{AE}$ with or without urticaria, suggesting that a positive HR-test is linked to urticaria and not AE, which could be confirmed in this study. Higher rates of positive HR-tests were found in the literature, possibly explained by a lower cutoff value in the majority of these studies as seen in Table III (3-5,7,10-19).

The main limitations of the present study are the retrospective design with data collection from the patients' medical records over a 20-year period. We cannot exclude possible bias in the study, as different colleagues have made the clinical observations and not all symptoms may be listed in the medical records. The HRtest became commercially available in our country in 2004, and has been used routinely in all patients with urticaria seen at our department between 2005 and 2013. A prospective study would be preferable, and should include a valid and reliable measure of disease activity; i.e. the Angioedema Activity Score (20).
We could not compare data with autologous serum or plasma skin tests (ASST and APST), as these are not routinely performed in our country. According to the findings of Berti et al., there does not seem to be any association between in vivo and in vitro tests in patients with CU (19), and the same could be true for AE. The performance of ASST and APST would be desirable to study in the future, to confirm these findings also in mono-symptomatic AE. In conclusion, we cannot see any diagnostic or therapeutic value of HR-test in mono-symptomatic AE.

\section{Acknowledgments}

The authors would like to thank Kristine Appel Uldall Pallesen, Kawa Khaled Ajgeiy and Shailajah Kamaleswaran, for contributing to the data collection.

CSL Behring and Shire are thanked for their continuous contribution to angioedema research.

\section{Conflicts of interest}

Dr. Eva Rye Rasmussen has collaborated with Shire and CSL Behring regarding angioedema research. This study was not directly supported financially. Dr. Rasmussen has received honorariums for lectures at angioedema meetings from Shire and MSD Norway.

A. Bygum has received research grant support and/or speaker I consulting fees from CSL Behring, Shire/Jerini AG and ViroPharma; and participated in a clinical trial for BioCryst and Jerini AG. She is an advisor for the HAE Scandinavian Patient Organization.

\section{References}

1. Goh CL, Tan KT. Chronic autoimmune urticaria: where we stand? Indian J Dermatol 2009; 54:269-74.

2. Konstantinou GN, Asero R, Ferrer M, Knol EF, Maurer M, Raap $\mathrm{U}$, et al. EAACI taskforce position paper: evidence for autoimmune urticaria and proposal for defining diagnostic criteria. Allergy 2013 ; 68:27-36.

3. Iqbal K, Bhargava K, Skov PS, Falkencrone S, Grattan CE. A positive serum basophil histamine release assay is a marker for ciclosporin-responsiveness in patients with chronic spontaneous urticaria. Clin Transl Allergy 2012; 2:19.

4. Grattan CE, Francis DM, Hide M, Greaves MW. Detection of circulating histamine releasing autoantibodies with functional properties of anti-IgE in chronic urticaria. Clin Exp Allergy 1991; 21:695-704.

5. Hide M, Francis DM, Grattan CE, Hakimi J, Kochan JP, Greaves MW. Autoantibodies against the high-affinity IgE receptor as a cause of histamine release in chronic urticaria. N Engl J Med 1993; 328:1599-604.

6. Sabroe RA, Fiebiger E, Francis DM, Maurer D, Seed PT, Grattan $\mathrm{CE}$, et al. Classification of anti-FcepsilonRI and anti-IgE autoantibodies in chronic idiopathic urticaria and correlation with disease severity. J Allergy Clin Immunol 2002; 110:492-9. 
7. Tedeschi A, Asero R, Lorini M, Marzano AV, Cugno M. Different rates of autoreactivity in patients with recurrent idiopathic angioedema associated or not with wheals. J Investig Allergol Clin Immunol 2012; 22:87-91.

8. Cicardi M, Aberer W, Banerji A, Bas M, Bernstein JA, Bork K, et al. Classification, diagnosis, and approach to treatment for angioedema: consensus report from the Hereditary Angioedema International Working Group. Allergy 2014; 69:602-16.

9. Zingale LC, Beltrami L, Zanichelli A, Maggioni L, Pappalardo E, Cicardi B, et al. Angioedema without urticaria: a large clinical survey. CMAJ 2006; 175:1065-70.

10. Grattan CE, O’Donnell BF, Francis DM, Niimi N, Barlow RJ, Seed PT, et al. Randomized double-blind study of cyclosporin in chronic 'idiopathic' urticaria. Br J Dermatol 2000; 143:365-72.

11. Platzer MH, Grattan CE, Poulsen LK, Skov PS. Validation of basophil histamine release against the autologous serum skin test and outcome of serum-induced basophil histamine release studies in a large population of chronic urticaria patients. Allergy 2005; 60:1152-6.

12. Szegedi A, Irinyi B, Gál M, Hunyadi J, Dankó K, Kiss E, et al. Significant correlation between the CD63 assay and the histamine release assay in chronic urticaria. Br J Dermatol 2006; 155:67-75.

13. Zuberbier T, Henz BM, Fiebiger E, Maurer D, Stingl G. Anti-FcepsilonRIalpha serum autoantibodies in different subtypes of urticaria. Allergy 2000; 55:951-4.
14. Godse KV, Nadkarni NJ, Jani G. Comparison of commercial histamine release test and autologous serum skin test in the diagnosis of autoimmune urticaria. Indian J Dermatol Venereol Leprol 2010; 76:413-5.

15. Hyry H, Elg P, Ranki A. A commercial histamine release test and autologous serum skin test in the diagnosis of autoimmune urticaria. Allergy 2006; 61:1147-8.

16. Sabroe RA, Grattan CE, Francis DM, Barr RM, Kobza Black A, Greaves MW. The autologous serum skin test: a screening test for autoantibodies in chronic idiopathic urticaria. Br J Dermatol 1999; 140:446-52.

17. Kaplan AP, Joseph K. Basophil secretion in chronic urticaria: autoantibody-dependent or not? J Allergy Clin Immunol 2007; 120:729-30.

18. Perez A, Woods A, Grattan CE. Methotrexate: a useful steroid-sparing agent in recalcitrant chronic urticaria. $\mathrm{Br} J$ Dermatol 2010; 162:191-4.

19. Berti A, Yacoub MR, Stahl PS, Falkencrone S, Casati L, Burastero $S$, et al. Histamine release positive test associates with disease remission in chronic spontaneous urticaria: a proof-of-concept study. Eur Ann Allergy Clin Immunol 2017; 49:154-60.

20. Weller K, Groffik A, Magerl M, Tohme N, Martus P, Krause K, et al. Development, validation, and initial results of the Angioedema Activity Score. Allergy 2013; 68:1185-92. 